\title{
An evaluation of the treatment of parapsoriasis with phototherapy ${ }^{*}$
}

\author{
Avaliação do tratamento da parapsoríase com fototerapia
}

\author{
Ida Alzira Gomes Duarte ${ }^{1}$ \\ Vanessa Alice M. Amorim² \\ Roberta Buense ${ }^{3}$
}

\author{
Karen Levy Korkes ${ }^{2}$ \\ Clarice Kobata ${ }^{3}$ \\ Rosana Lazzarini ${ }^{3}$
}

\begin{abstract}
Whether parapsoriasis represents an early stage of T-cell cutaneous lymphoma is still the subject of controversy. We evaluated the efficacy of phototherapy in the treatment of parapsoriasis and its relation with TCCL. Patients diagnosed with parapsoriasis and treated with phototherapy PUVA or UVB-NB were selected. Between 1 to 8 years following treatment the evolution of their disease was evaluated. In 62 patients the cure rate was $79.3 \%$ and $17.2 \%$ showed improvement of the lesions. Only two patients developed full blown T-cell cutaneous lymphoma. Phototherapy is an excellent treatment for parapsoriasis, with high cure rates, regardless of the type of phototherapy employed. Of the 62 patients under study, parapsoriasis showed no general tendency to progress to T-cell cutaneous lymphoma.

Keywords: Parapsoriasis; Phototherapy; PUVA therapy; Ultraviolet therapy

Resumo: Há controvérsias se parapsoríase pode evoluir para linfoma Cutâneo de Células T. Neste trabalho avaliou-se eficácia da fototerapia no tratamento da parapsoríase e sua relação com linfoma Cutâneo de Células T. Selecionaram-se pacientes com parapsoríase tratados com PUVA ou UVB-NB. Após um-oito anos do tratamento, pacientes foram contatatos para avaliar a evolução da doença. Em 62 pacientes, a taxa de cura foi de $79,3 \% ; 17,2 \%$ apresentaram melhora de lesões. Apenas dois pacientes evoluíram para linfoma Cutâneo de Células T. A fototerapia mostrou-se eficaz no tratamento da parapsoríase, independente do tipo de fototerapia utilizada. Nos casos estudados, parapsóríase não mostrou tendência a se desenvolver em linfoma Cutâneo de Células T. Palavras-chave: Fototerapia; Parapsoríase; Terapia PUVA; Terapia ultravioleta
\end{abstract}

The etiology of parapsoriasis is still unknown. ${ }^{1-3}$ Previous work has however shown that this disease probably represents different stages of a lymphoproliferative disorder, ranging from chronic dermatitis to T-cell cutaneous lymphoma (TCCL). ${ }^{4.8}$

Phototherapy is indicated for all types of parapsoriasis and its clinical variants. The rationale behind the therapeutic use of phototherapy stems from its anti-inflammatory and immunosuppressive effects. ${ }^{9,10}$

This was a retrospective, cross-sectional, multicentric study examining all of the patients diagnosed with parapsoriasis (according the clinic and the hystopathology) and treated with phototherapy at the Dermatology Clinic of the Santa Casa de São Paulo and at a private clinic from 2006 to 2009. It is important to emphasize that the patients treated at the Dermatology Clinic and those treated at the private clinic were subjected to phototherapy sessions using similar machines. Furthermore, the treatment indications were similar for all patients, and the same doctors performed the treatment supervision and followups. The objective of this study was to evaluate the efficacy of two different phototherapy treatments in patients suffering from parapsoriasis and to examine

Approved by the Advisory Board and accepted for publication on 25.05.2012.

* Study conducted in the Dermatology Clinic of the Irmandade da Santa Casa de Misericórdia de São Paulo - São Paulo (SP), Brazil.

Conflict of interest: None

Financial funding: None

PhD - Attending Physician at the Irmandade da Santa Casa de Misericórdia de São Paulo - São Paulo (SP), Brazil.

Student at the Medical Sciences Faculty, Santa Casa de São Paulo (FCMSCSP) - São Paulo (SP), Brazil.

Master's Degree in Dermatology awarded by the University of São Paulo (USP) - Assistant in the Dermatology Clinic of the Irmandade da Santa Casa de Misericórdia de São Paulo - São Paulo (SP), Brazil. 
the progression of disease, monitoring disease remission, recurrence, and progression to TCCL.

Patients presented for twice weekly sessions of phototherapy. Most were treated with PUVA given that UVA has greater penetration than UVB and can be effective even in the middle layer of the dermis., UVB-NB was used when psoralen was contraindicated or when patients were using photosensitizing drugs.

Epidemiological data and the number of sessions completed were analyzed to compare the two treatment groups. The patient was considered cured when the histopathology of the skin, where a lesion had existed before treatment, showed normal skin.

All patients were contacted by telephone at least one year following the end of treatment to determine the progression of their clinical condition.

The data obtained were tabulated in an Excel spreadsheet and analyzed using accepted statistical methods.

A total of 62 patients were evaluated - 34 males and 28 females. The age of the patients ranged between 23 and 92, with an average of 33. Regarding the type of lesion, 45 (73\%) had large plaques and 17 (27\%) small plaques. 5 of them had digitiform lesions.

Of the 62 patients the lesions of $55(88.7 \%)$ were cured. 45/62 were treated with PUVA and 17/62 with UVB-NB. In both types of phototherapy, the average treatment consisted of 30 sessions over two and a half months. The total number of sessions ranged between 18 and 90 . No difference was observed in relation to the time and number of sessions between the two types of phototherapy.
The treatment success rate was similar in the two groups: $41 / 45$ (91.1\%) treated with PUVA and $14 / 17(82.3 \%)$ treated with UVB-NB progressed to cure, with no statistically significant difference (Yates correction $\left.\mathrm{X}^{2}=0.862, \mathrm{P}=0.7641\right)$. The patients who did not exhibit complete remission of their lesions during treatment nevertheless showed lesion improvements (Table 1).

When disease progression was assessed in patients between one and eight years after treatment, 46/62 reported that they were cured of their lesions, exhibiting no lesions at the time they were contacted.10/62 patients showed improvements and two had progressed to TCCL. We were unable to contact the remaining four patients.

Patients were also examined according to the type of phototherapy treatment they had been submitted to. 35/45 patients treated with PUVA were without parapsoriasis lesions, six had lesions, and two showed progression to TCCL. It was not possible to establish contact with the other two patients. 11/17 patients treated with UVB-NB did not exhibit lesions, while four did. It was not possible to contact the remaining two patients (Table 2). A chi-squared test revealed no statistically significant difference in disease progression in patients based on the type of phototherapy they had received $(\mathrm{P}>0.05)$.

The present study investigated the efficacy of phototherapy in the treatment of parapsoriasis. The study also evaluated disease progression in each of the patients at least one year after treatment. An overall parapsoriasis cure rate of $78.18 \%$ was observed for phototherapy treatment.

TABLE 1: The treatment of parapsoriasis with phototherapy - 62 patients

\begin{tabular}{llll}
\hline Response to treatment & Cure & Improvement & Total \\
\hline Type of phototherapy & $88.7 \%$ & $11.3 \%$ & $100 \%$ \\
PUVA & 41 & 4 & 45 \\
UVB-NB & 14 & 3 & 17 \\
Total & 55 & 7 & 62 \\
\hline
\end{tabular}

Yates correction $\mathrm{X} 2=0.862 \mathrm{P}=0.7641$

TABLE 2: Progression of parapsoriasis in patients treated with phototherapy

\begin{tabular}{llll}
\hline $\begin{array}{l}\text { Evolution } \\
\text { Type of Treatment }\end{array}$ & No Lesion & With Lesion & Total \\
\hline PUVA & 35 & 8 & $43^{*}$ \\
UVB-NB & 11 & 4 & $15^{*}$ \\
Total & 46 & 10 & 58 \\
\hline
\end{tabular}

Yates correction $\mathrm{X} 2=0.272 \mathrm{P}=0.6014$

*2 patients were not contacted 
Although UVB-NB only affects the epidermis and superficial dermis, it was quite effective in treating parapsoriasis.

Among the patients who exhibited poor responses to treatment and only moderate lesion improvements, two patients exhibited progression of parapsoriasis to TCCL (3.2\%). These two patients were women aged 35 and 37 who had received a substantial number of PUVA sessions (70 and 66). Their lesion improvements were unsatisfactory from the outset and responded poorly throughout the entire course of treatment. This finding raises some doubt as to whether these were really cases in which parapsoriasis turned into TCCL or whether an initial diagnosis of TCCL was missed due to a lack of histopathological evidence.

The good responses to therapy observed and the low frequency of disease progression allows us to suggest phototherapy as an appropriate option for the treatment of parapsoriasis.

\section{REFERENCES}

1. Belousova IE, Vanecek T, Samtsov AV, Michal M, Kazakov DV. A patient with clinic pathologic features of small plaque parapsoriasis presenting later with plaquestage mycosis fungoides: report of a case and comparative retrospective study of 27 cases of "nonprogressive" small plaque parapsoriasis. J Am Acad Dermatol. 2008; 59:474-82.

2. Lessin SR, Ross EA, Wu H. Treatment of parapsoriasis with bexarotene $1 \%$ gel. Int J Dermatol. 2008,47:1325-7.

3. Hofer A, Cerroni L, Kerl H, Wolf P. Narrowband (311-nm) UV-B therapy for small plaque parapsoriasis and early-stage mycosis fungoides. Arch Dermatol. 1999: 135:1377-80.

4. Vakeva L, Sarna S, Vaalasti A, Pukkala E, Kariniemi AL, Ranki A. A retrospective study of the probability of the evolution of parapsoriasis en plaques into mycosis fungoides. Acta Derm Venereol 2005:85:318-23.

5. Kikuchi A, Naka W, Harada T, Sakuraoka K, Harada R, Nishikawa T. Parapsoriasis en plaques: its potencial for progression to malignant lymphoma. J Am Acad Dermatol. 1993;29:419-22.

6. Bordignon M, Belloni-Fortina A, Pigozzi B, Saponeri A, Alaibac M. The role of immunohistochemical analysis in the diagnosis of parapsoriasis. Acta Histochem 2011;113:92-5

7. Duarte I, Buense R, Kobata C. Fototerapia. An Bras Dermatol. 2006;81:74-82.
8. Herzinger T, Degitz K, Plewig G, Röcken M. Treatment of small plaque parapsoriasis whith narrow-band $(311 \mathrm{~nm})$ ultraviolet B: a retrospective study. Clin Exp Dermatol. 2005;30:379-81.

9. Cestari T, Pessato S, Corrêa G. Fototerapia - aplicações clínicas. An Bras Dermatol. 2007;82:7-21

10. Aydogan K, Karadogan SK, Tunali S, Adim SB, Ozcelik T. Narrowband UVB phototherapy for small plaque parapsoriasis. J Eur Acad Dermatol Venereol. 2006; 20:573-7.

How to cite this article: Duarte IAG, Korkes KL, Amorim VAM, Kobata C, Buense R, Lazzarini R. An Evaluation of the Treatment of Parapsoriasis with Phototherapy. An Bras Dermatol. 2013;88(2):306-8. 